Original Research

\title{
Origins of Polycyclic Aromatic Hydrocarbons in Sediments from the Danube and Sava Rivers and Their Tributaries in Serbia
}

\author{
Dragan Crnković ${ }^{1 *}$, Zoran Sekulić1, Dušan Antonović ${ }^{2}$, Aleksandar Marinković², \\ Slađana Popovićc Jasmina Nikolić $^{2}$, Saša Drmanić ${ }^{2}$ \\ ${ }^{1}$ Public Health Institute Belgrade, Belgrade, Serbia \\ ${ }^{2}$ Department of Organic Chemistry, Faculty of Technology and Metallurgy, University of Belgrade, \\ Belgrade, Serbia \\ ${ }^{3}$ Institute for Chemistry, Technology and Metallurgy, Department of Ecology and Technoeconomics, \\ University of Belgrade, Belgrade, Serbia
}

Received: 27 March 2019

Accepted: 25 July 2019

\begin{abstract}
This study focussed on a comprehensive investigation on the state of pollution and identification of potential sources of contamination of some river sediments in Serbia by polycyclic aromatic hydrocarbons (PAHs), and is the basis for setting up further monitoring programs. The sediment quality of the Danube River (km 1433-845) and its tributaries in Serbia, including the Sava River (km 202-1), were analysed with respect to PAHs and total organic carbon (TOC). We found that total PAH concentration in the sediments from the Danube and its tributaries (10.0-4140 $\left.\mathrm{g} \mathrm{kg}^{-1}\right)$ was lower than total PAH concentration in Sava River sediments (265.1-11272 $\left.\mathrm{g} \mathrm{kg}^{-1}\right)$. Principal component analysis showed that concentrations of benzo $[a]$ anthracene, chrysene, pyrene, fluoranthene, indeno[1,2,3-cd]pyrene, benzo $[a]$ pyrene, benzo $[b]$ fluoranthene and benzo $[k]$ fluoranthene in the sediments were correlated with TOC. The diagnostic ratios anthracene/(anthracene+phenanthrene) and fluoranthene/(fluoranthene+pyrene) were calculated to evaluate the emission sources of the PAHs. Therefore, these ratios indicated the predominantly pyrogenic source of the PAHs in the sediments. Results have also shown that river sediments in the Danube and Sava rivers and their tributaries were not recently polluted with PAHs, excluding only one location - S4, downstream of Šabac and characterized by heavily polluted sediment.
\end{abstract}

Keywords: river sediment, PAHs, pollution sources, Danube River, Sava River

*e-mail: dragan.crnkovic@zdravlje.org.rs 


\section{Introduction}

Polycyclic aromatic hydrocarbons (PAHs) are organic compounds that are mostly colourless, white or pale yellow solids. They are a group of several hundred chemically related compounds, environmentally persistent, with various structures and different levels of toxicity. PAHs enter the environment through many different routes and disperse through air and water as a result of many human activities. In nature, they are usually found as a complex mixture of two or more compounds [1-4].

The sources of PAHs that enter the environment are numerous and can be natural or synthetic. The major PAH sources in the environment are pyrogenic, petrogenic and biological. When organic substances (i.e., fossil fuel or biomass) are exposed to high temperatures under no oxygen or low oxygen conditions, pyrogenic PAHs are formed [5]. The main sources of pyrogenic PAHs are different industrial processes, urban runoff, oil spills, combustion emissions and ship traffic - all of which are anthropogenic input. Additional anthropogenic sources include vehicle exhaust emissions, tire degradation, industrial emissions from catalytic cracking, air blowing of asphalt, coking coal, domestic heating emissions from coal, oil, gas and wood, refuse incineration and biomass burning [6-8]. Thus, these PAHs are usually found in higher concentrations in urban areas and commonly distributed by atmospheric deposition as well as urban runoff. Petrogenic PAHs, on the other hand, are formed during crude oil maturation and similar processes. They are introduced into the environment naturally by oil seeps, or anthropogenically by the spills of crude or refined petroleum products [9-17]. Finally, PAHs can be the products of some bacteria and plants, and thus they are called biologically produced PAHs [5, 9-17]. Based on physical, chemical and biological properties, PAHs are classified into high molecular weight (HMW, 4-6 rings) and low molecular weight (LMW, 2-3 rings) types. Some PAH ratios and indices can indicate the sources of the PAHs that occur in sediments or other environments $[18,19]$. In aquatic environments, a common indicator of weathering is the low molecular weight/high molecular weight (LMW/HMW) ratio. PAH profiles can be used to distinguish these two origins; pyrogenic PAHs are generally characterised by the dominance of HMW, over those with LMW [20].

Urban development often results in physically modified rivers, for example, for navigation as well as minimisation of flooding [21]. On the other hand, urban rivers are frequently contaminated as a result of anthropogenic activities like shipping, road use and industrial discharge, but also they often receive discharges from urban drainage networks [22, 23]. Consequently, the aquatic ecosystem becomes polluted with different contaminants, but also with PAHs that can represent serious problem due to the toxicity and accumulative behaviour [24-28]. They accumulate in river sediments, making them continuous sources of toxic and hazardous substances that can affect aquatic organisms, wildlife and finally humans through the food chain [29]. If the sediment is disturbed, it can be resuspended and contaminants can enter the water and affect the whole ecosystem [30].

Existing PAHs in the environment are an ecological issue, since they are dangerous for humans. Considering living organisms, most PAHs have toxic, mutagenic, and/or carcinogenic properties, where the level of toxicity depends on the number of rings. They interfere with the function of cellular membranes and membraneassociated enzyme systems, leading to numerous dysfunctions in the human body [31]. Taking into account 126 United States Environmental Protection Agency (US EPA) priority pollutants listed by the Clean Water Act, 16 of them are PAHs, with the following seven being known as carcinogens and mutagens: (chrysene, benzo $[a]$ anthracene, benzo $[k]$ fluoranthene, benzo $[b]$ fluoranthene, benzo $[a]$ pyrene, indeno $[1,2,3-c d]$ pyrene and dibenzo $[a h]$ anthracene as Group B, probable human carcinogens) [32]. Understanding the different mechanisms by which PAHs are introduced into the environment can help to limit human exposure to these compounds.

The total organic carbon (TOC) in a sediment is an important parameter during environmental evaluation because it is an indicator of pollution and eutrophication rate. That rate is proportional to the content of organic matter that is the primary source of food for benthic organisms in aquatic environments. However, too much organic matter can cause oxygen depletion in the sediment and the overlying water layer and can have harmful effects on benthic organisms and fish. PAH behaviour in sediment is controlled by the compounds' stable absorption on the surface of the sediment. PAHs with three or more rings tend to be strongly absorbed, first onto aggregates smaller than $50 \mu \mathrm{m}$. However, the fact is that PAHs show a strong affinity to organic matter content, and concentrations of PAHs in sediments are controlled by the organic matter content [33, 34]. Many studies have shown a positive correlation between PAHs and TOC, even though it is not completely clear which part of TOC plays a key role in controlling PAH distribution in sediments [35].

For a preliminary risk assessment, the contents of PAHs in this study were compared to Dutch recommendations and Serbian regulations of pollutant substances limit values in surface water, groundwater and sediment (Circular on Target Values and Intervention Values and Intervention Values for Soil Remediation Netherlands Government Gazette, 2000 and Official Gazette of RS, 50/2012, in Serbian). Dutch standards and Serbian legislation for contaminated sediments correspond to class 0 (non-polluted), class 1 (slightly polluted), class 2, (moderately polluted), class 3 (heavily polluted) and class 4 (extremely polluted sediment) [36]. A total of 16 PAHs were examined, and 10 were analyzed for the purpose of classifying according 
to the Dutch and Serbian regulations; naphthalene (Nap), anthracene (Ant), benzo[a]anthracene (Baa), benzo[k]fluoroanthene (Bkf), benzo[a]pyrene (Bap), chrysene (Chr), phenanthrene (Phe), fluoranthene (Fla), indeno[1,2,3-cd]pyrene (Inp) benzo[ghi]perylene (Bpe) and, following the U.S. EPA priority pollutant list, 6 were added (for a total of 16) for the purpose of calculating the diagnostic ratio for acenaphthene (Ane), acenaphthylene (Any), fluorene (Flu), pyrene (Pyr), benzo $[b]$ fluoranthene $(\mathrm{Bbf})$ and dibenzo $[a h]$ anthracene (Daa).

For the purpose of this study, the data were obtained during 2008 and 2013. The aim of this research was to provide important information on PAH levels in surface sediments of the Danube River and Sava River, but also to identify possible sources of polycyclic aromatic hydrocarbons and to monitor the pollution of aquatic ecosystems. Principal component analysis was utilised to investigate the relationships of the PAHs studied with TOC in the sediments, while the likely origins of the PAHs in the sediments were considered using ratios of specific PAHs.

\section{Study Area}

The Danube is the second-longest $(\sim 2,800 \mathrm{~km})$ river in Europe. It rises in the Black Forest region of Germany and reaches its discharge point in the Black Sea, running through central and Eastern Europe. The Danube's total catchment area $\left(801,500 \mathrm{~km}^{2}\right)$, encompasses 19 countries and is home to 81 million people. In Serbia, the Danube is $588 \mathrm{~km}$ long.

The Sava is $945 \mathrm{~km}$ long, rises in Slovenia, enters Serbia at $210.8 \mathrm{~km}$ and ends at its confluence with the
Danube, joining its right bank at $1169.9 \mathrm{~km}$ in Belgrade, Serbia. The Sava is the largest Danube tributary by discharge $\left(1,564 \mathrm{~m}^{3} \mathrm{~s}^{-1}\right.$ average $)$ and the second largest by catchment area. The Sava River basin covers $95,700 \mathrm{~km}^{2}$ of land in former Yugoslavia, before discharging into the Danube at Belgrade, Serbia. For the supply of drinking water, both large cities and small villages in the Sava catchment area rely on ground water. Only Belgrade, the Serbian capital, uses both ground water and river water. Activities such as agriculture, forestry, electric power generation, sport and recreation occur in and around this river. Furthermore, changes in the water environment caused by industrialisation and human activity have affected the ecological system of the Sava catchments [37].

Pollution by PAHs in the Danube and the Sava River basins has been reported in many studies. The PAHs in the Danube and Sava sediments in Serbia are currently analysed by official control networks as well as scientific research. Such pollution monitoring has also involved analysing different quality criteria $[36,38]$. Twenty-one sampling sites were chosen along a $573 \mathrm{~km}$ stretch of the Danube in Serbia, from Bezdan (river-km 1425) down to Radujevac (river-km 852). One of the main tributaries of the Danube is the Sava. Hence, 10 sampling locations were selected along the Sava, encompassing a $202 \mathrm{~km}$-long reach of the river, from Jamena (river-km 202) to its outfall into the Danube River, Kapetanija (river-km 1). The sampling points are presented in Fig. 1 and Table 1.

The study also took into consideration the influence of the large tributaries of the Danube (the Tisa, the Sava, and the Velika Morava rivers). The following

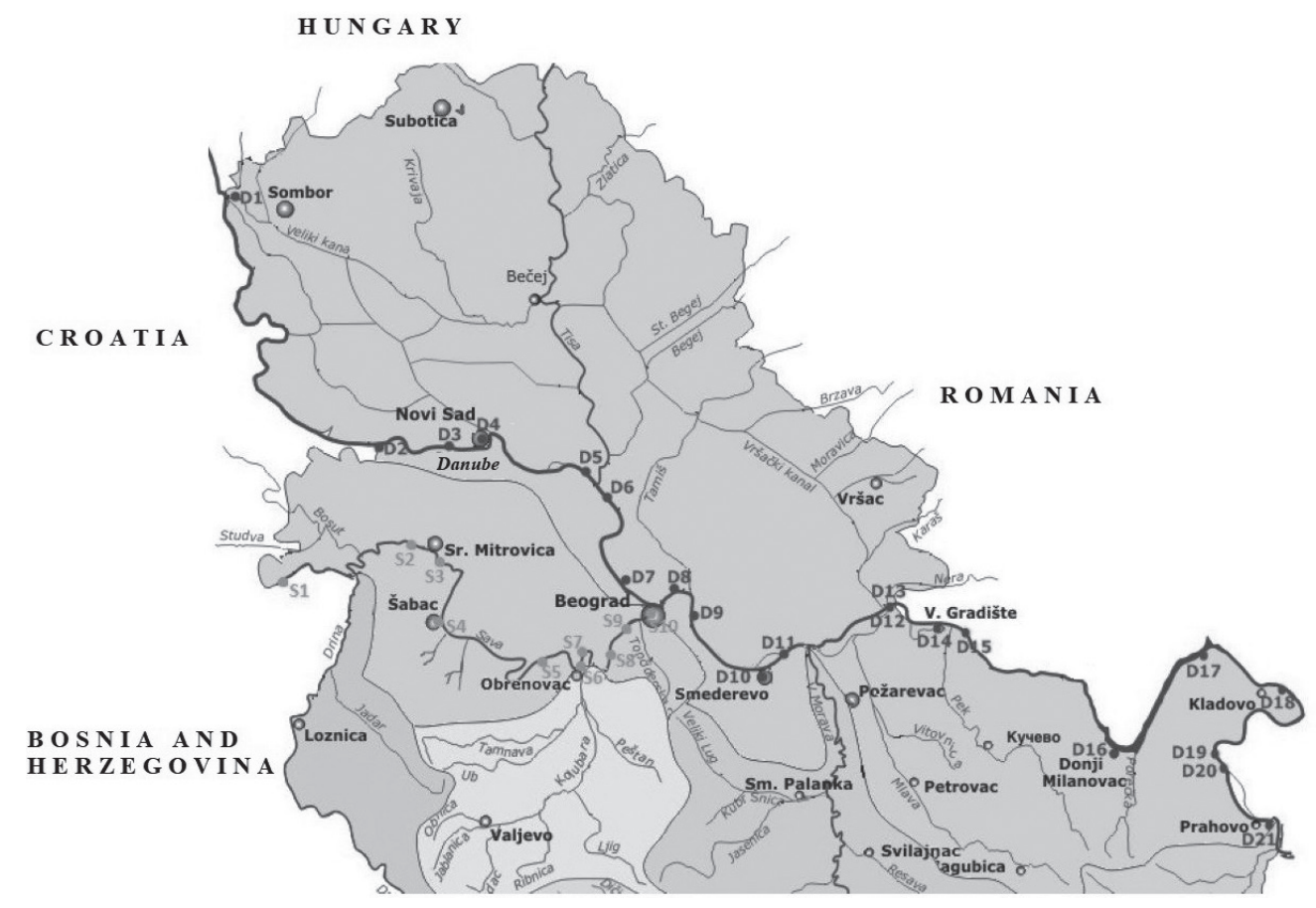

Fig. 1. Sediment sampling sites along the Serbian part of the Danube and Sava rivers. 
Table 1. Key to sampling locations of the Danube and Sava rivers.

\begin{tabular}{|c|c|}
\hline Location name-Danube & Mark on the map \\
\hline 1. Bezdan & D1 \\
\hline 2. Neštin & D2 \\
\hline 3. Ledinci & D3 \\
\hline 4. Novi Sad & D4 \\
\hline 5. Stari Slankamen & D5 \\
\hline 6. Surduk & D6 \\
\hline 7. Zemun & D7 \\
\hline 8. Bela Stena & D8 \\
\hline 9. Beograd Vinča & D9 \\
\hline 10. Smederevo & D10 \\
\hline 11. Kovin's bridge & D11 \\
\hline 12. Ram & D12 \\
\hline 13. Banatska Palanka & D13 \\
\hline 14. Veliko Gradište & D14 \\
\hline 15. Golubac & D15 \\
\hline 16. Donji Milanovac & D16 \\
\hline 17. Tekija & D17 \\
\hline 18. Mala Vrbica & D18 \\
\hline 19. Brza Palanka & D19 \\
\hline 20. Mihajlovac & D20 \\
\hline 21. Radujevac & D21 \\
\hline Location name-Sava & Mark on the map \\
\hline 1. Jamena & S1 \\
\hline 2. Upstream of Sremska Mitrovica & $\mathrm{S} 2$ \\
\hline 3. Downstream of Sremska Mitrovica & S3 \\
\hline 4. Sava downstream of Šabac & S4 \\
\hline 5. Sava Skela & S5 \\
\hline 6. Sava Zabran & S6 \\
\hline 7. Sava Duboko & S7 \\
\hline 8. Sava Ostružnica & S8 \\
\hline 9. Sava Makiš & S9 \\
\hline 10. Sava Kapetanija & S10 \\
\hline
\end{tabular}

tributaries of the Danube were sampled and analysed: Tamiš, Morava, Mlava, Pek, Tisa, River Porečka and Pek, as well as Kolubara, a Sava tributary. The sediment samples were taken from July 2016 to October 2016: 18 from the left bank and 10 from the right Danube bank (the number of samples is different due to the availability/unavailability of individual sampling points), and 8 from the left and 8 the from the right Sava bank, and 10 from the middle rivers and 12 from tributaries of the Danube River. Sampling was performed using a grab sampler (Van Veegrabs Eijkelkamp), at a depth of $0-10 \mathrm{~cm}$ from the top of the sediment surface, in accordance with standard procedures [39].

\section{Materials and Methods}

The fine fraction $(<63 \mu \mathrm{m})$ sieved from each sediment was analysed for $16 \mathrm{PAH}$ compounds, according to ISO 18287:2006, method B [40], which called for $10 \mathrm{~g}$ to $25 \mathrm{~g}$ of the field-moist sample sediments being weighed in a $500 \mathrm{ml}$ conical flask. After adding $1 \mathrm{ml}$ of the mixed internal standard solution $(10 \mu \mathrm{g}$ of each deuterated PAH) and subsequently $50 \mathrm{ml}$ of water, $40 \mathrm{~g}$ of sodium chloride, $100 \mathrm{ml}$ of acetone, and $50 \mathrm{ml}$ of petroleum ether to the test sample. Then the flask was closed with the screw cap provided with a polytetrafluoroethylene inlay and extracted by shaking thoroughly on a shaking machine for at least $6 \mathrm{~h}$. After precipitate appeared, the supernatant organic layer was decanted into a conical flask and the extract was dried over anhydrous sulphate for $1 \mathrm{~h}$. An aliquot $(30 \mathrm{ml})$ of the dried extract was transferred to the concentration apparatus and $100 \mu \mathrm{l}$ of isooctane was added for protection. Then the aliquot was concentrated to about $2 \mathrm{ml}$ using a water bath set at $40^{\circ} \mathrm{C}$, with the concentration apparatus under reduced pressure. The last concentration step was performed using a gentle stream of nitrogen at room temperature. The solution, which was then suitable for GC-MS analysis, contained nominally $1 \mu \mathrm{g} \mathrm{ml}^{-1}$ of each of the deuterated PAHs. An adsorption column was prepared by placing a small plug of glass wool at the bottom of the chromatographic tube and packing it dry with $4 \mathrm{~g}$ of silica gel. About $1 \mathrm{~cm}$ of anhydrous sodium sulphate was added to the top of the column. To condition the column, it was eluted with $10 \mathrm{ml}$ of petroleum ether. As soon as the elution solvent reached the top of the column packing, the concentrated extract (2 ml) was transferred to the top of the column using a Pasteur pipette. The concentrator was rinsed twice with $1 \mathrm{ml}$ of the elution solvent and transferred to the top of the chromatographic column. It was eluted with approximately $70 \mathrm{ml}$ of petroleum ether and the eluate was collected in a point-shaped, calibrated test tube. Then $100 \mu \mathrm{l}$ of isooctane was added and the solution concentrated at room temperature under nitrogen to about $0.5 \mathrm{ml}$. An appropriate amount of cyclohexane was added to obtain a defined volume $(2 \mathrm{ml})$ of the final solution. This final solution, which was suitable for GC-MS analysis, contained nominally $1 \mu \mathrm{g} \mathrm{ml}^{-1}$ of each of the deuterated PAHs as the internal standard.

Quantitative analysis of the sediment extracts was carried out by gas chromatography with a mass spectrometer detector attached. Concentrations were determined for 16 PAHs in all sediments using a Hewlett Packard (HP) 6890 series II GC, equipped with HP 5973 mass selective detector (MSD) and 
Table 2. Target, MAC and intervention PAH concentrations ( $\left.\mathrm{mg} \mathrm{kg}^{-1}\right)$.

\begin{tabular}{|c|c|c|c|c|}
\hline Parameter & Abbreviations & Target value & MAC value & Intervention value \\
\hline $\mathrm{PAH}^{(1)}$ & & 1 & 10 & 40 \\
\hline Naphtalene & Nap & 0.001 & 0.1 & \\
\hline Anthracene & Ant & 0.001 & 0.1 & \\
\hline Phenanthrene & Phe & 0.005 & 0.5 & \\
\hline Fluoranthene & Fla & 0.03 & 3 & \\
\hline Benzo $[a]$ anthracene & Baa & 0.003 & 0.4 & \\
\hline Chrysene & $\mathrm{Chr}$ & 0.1 & 11 & \\
\hline Benzo $[k]$ fluoranthene & Bkf & 0.02 & 2 & \\
\hline Benzo $[a]$ pyrene & Bap & 0.003 & 3 & \\
\hline Benzo $[g, h, i]$ perylene & Bpe & 0.08 & 8 & \\
\hline Indeno $[1,2,3-c d]$ pyrene & Inp & 0.06 & 6 & \\
\hline
\end{tabular}

(1) $\mathrm{PAH}$ (sum of 10) here represents the total of naphtalene, anthracene, benzo[ $a]$ anthracene, benzo $[k] f l u o r o a n t h e n e, ~ b e n z o[a] \operatorname{pyrene}$, chrysene, phenanthrene, fluoranthene, indeno[ $[1,2,3-c d]$ pyrene and benzo[ $g h i]$ perylene

HP-5MS capillary column $(30 \mathrm{~m} \times 0.25 \mathrm{~mm}$ i.d. with $0.25 \mu \mathrm{m}$ film thickness). The splitless injection of $1 \mu \mathrm{L}$ of sample was conducted using the autosampler HP 6890. The column temperature started at $60^{\circ} \mathrm{C}(2 \mathrm{~min}$ hold), followed by an increase to $310^{\circ} \mathrm{C}$ at $7^{\circ} \mathrm{C} \mathrm{min}^{-1}$ with a final holding time of $20 \mathrm{~min}$. The carrier gas was

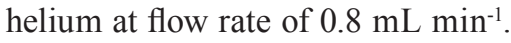

Quantification was performed using the internal calibration method based on a five-point calibration curve for individual components. Method blanks (solvent), spiked blanks (standard spiked into solvent), matrix spikes/matrix spike duplicates, sample duplicates and standard reference material (CRM 141) [41] were routinely analysed with the sediment samples.

TOC in sediment was determined by using an Analytik Jena AG-multi EA 2000 elemental analyzer in accordance with method SRPS EN 13137:2005. Sediment $\mathrm{pH}$ was measured according to the SRPS ISO 10390:2007 method using a pH meter (Orion 5-multistar) with a glass electrode in a 1:5 (volume fraction) suspension of sediment in water. Data was statistically processed using CANOCO for Windows, Version 5.0. Principal component analysis (PCA) was used to show the relationship between the 16 PAHs and the supplementary variables: side of the rivers (left or right), $\mathrm{pH}$ and TOC.

\section{Indicative and Target Levels of Sediment Contamination}

Indicative levels for serious sediment contamination and the accompanying target (Dutch and Serbian legislative) values for soil/sediment are presented in Table 2. The given concentrations are from a standard type of sediment with $10 \%$ organic matter and $25 \%$ clay. For the target value, maximum allowable concentration
(MAC) and intervention value of $\mathrm{PAH}$, no soil type correction factor was used for sediments with an organic matter content of up to $10 \%$ or for sediments with an organic matter content above $30 \%$. For sediment with an organic matter content up to $10 \%$ a value of 1 was used (40 mg kg-1), and for soils with an organic matter content from $30 \%$ upwards a value of 3 was used $\left(120 \mathrm{mg} \mathrm{kg}^{-1}\right)$. For organic matter content between $10 \%$ and $30 \%$, the following soil type correction formula was used:

$(\mathrm{SW}) \mathrm{b}=1 \times(\%$ organic matter $/ 10)$,

$(\mathrm{IW}) \mathrm{b}=40 \times(\%$ organic matter/10)

...in which $(\mathrm{SW}, \mathrm{IW}) \mathrm{b}=$ target value, the intervention value for the soil to be assessed \% organic

Table 3. PAHs $\left(\mu \mathrm{g} \mathrm{kg}^{-1}\right)$ in Danube River sediments.

\begin{tabular}{|c|c|c|c|}
\hline $\begin{array}{c}\text { Danube sampling } \\
\text { locations }\end{array}$ & PAHs $^{1}$ & $\begin{array}{c}\text { Danube sampling } \\
\text { locations }\end{array}$ & PAHs $^{1}$ \\
\hline Bezdan & 481.1 & Ram & 326.0 \\
\hline Neštin & 2140 & Banatska Palanka & 360.0 \\
\hline Ledinci & 795.0 & Veliko Gradište & 770.0 \\
\hline Novi Sad & 558.0 & Golubac & 1020.0 \\
\hline Stari Slankamen & 620.0 & Donji Milanovac & 678.0 \\
\hline Surduk & 428.0 & Tekija & 1675.0 \\
\hline Zemun & 480.0 & Mala Vrbica & 650.0 \\
\hline Bela Stena & 288.0 & Brza Palanka & 380.0 \\
\hline Beograd-Vinča & 336.9 & Mihajlovac & 615.0 \\
\hline Kovin's bridge & 514.0 & Radujevac & 560.0 \\
\hline
\end{tabular}

${ }^{1} \mathrm{PAHs}=$ the sum of the identified PAHs in the examined sediments. 
Table 4. PAHs $\left(\mu \mathrm{g} \mathrm{kg}^{-1}\right)$ in Sava River sediments.

\begin{tabular}{|c|c|c|c|}
\hline $\begin{array}{c}\text { Sava sampling } \\
\text { locations }\end{array}$ & PAHs $^{1}$ & $\begin{array}{c}\text { Sava sampling } \\
\text { locations }\end{array}$ & PAHs $^{1}$ \\
\hline Jamena & 349.7 & Sava Skela & 550.0 \\
\hline $\begin{array}{c}\text { Downstream of } \\
\text { Sremska Mitrovica }\end{array}$ & 711.0 & Sava Zabran & 416.2 \\
\hline $\begin{array}{c}\text { Upstream of Sremska } \\
\text { Mitrovica }\end{array}$ & 745.0 & Sava Duboko & 595.3 \\
\hline $\begin{array}{c}\text { Sava downstream } \\
\text { of Šabac }\end{array}$ & 11272 & Sava Makiš & 346.0 \\
\hline Sava Kapetanija & 337.9 & Sava Ostružnica & 265.1 \\
\hline
\end{tabular}

${ }^{1}$ PAHs $=$ the sum of the identified PAHs in the examined sediments.

matter $=$ measured percentage of organic matter in the soil to be assessed.

The PAH considered in Dutch standards ( 210 Dutch PAHs) is the sum of three low molecular weight (LMW) PAHs: Nap, Phe, Ant and seven high molecular weight (HMW) PAHs: Fla, Baa, Chr, Bap, Bkf, Inp and Bpe. The PAHs in the river sediments were classified according to the Dutch national evaluation scheme and the relevant Serbian national regulation.

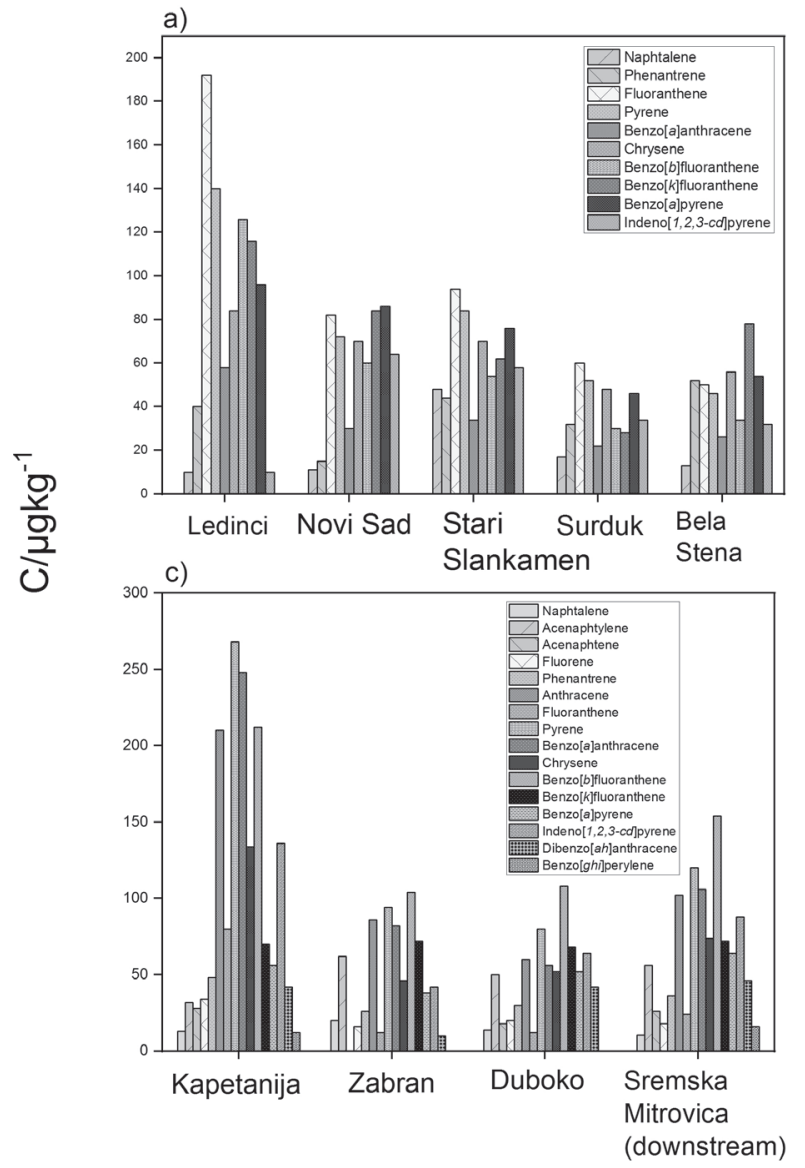

Table 5. PAHs $\left(\mu \mathrm{g} \mathrm{kg}^{-1}\right)$ in sediments from Danube tributaries, excluding the Sava.

\begin{tabular}{|c|c|c|c|}
\hline Sampling points & PAHs $^{1}$ & Sampling points & PAHs $^{1}$ \\
\hline Begej-Srpski Itebej & 4140 & Velika Morava & 112.0 \\
\hline $\begin{array}{c}\text { Begej-confluence of } \\
\text { Tisa }\end{array}$ & 1660 & Pek & 10.0 \\
\hline Tisa-Martonoš & 322.0 & Porečka river & 140.0 \\
\hline Tisa-Novi Bečej & 302.0 & Tamiš & 322.0 \\
\hline Tisa Titel & 1560 & Tisa-Žabalj bridge & 722.0 \\
\hline $\begin{array}{c}\text { Kolubara } \\
\text { (tributary of Sava) }\end{array}$ & 220.0 & Timok & 104.0 \\
\hline
\end{tabular}

${ }^{1}$ PAHs $=$ the sum of the identified PAHs in the examined sediments.

\section{Results and Discussion}

\section{PAHs}

In the river sediments PAHs are presented in Tables 3-5 and ranged from 10 to $4140 \mu \mathrm{g} \mathrm{kg}^{-1}$ in Danube River sediments and its tributaries. PAH concentrations in sediments from the Sava were higher than those
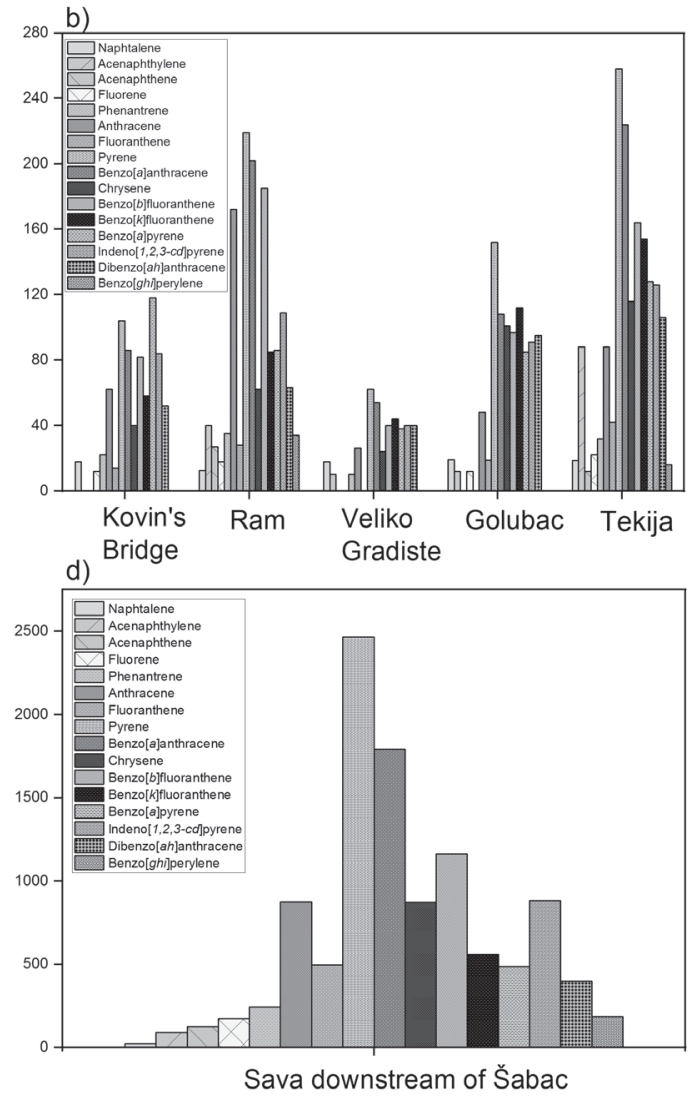

Fig. 2. PAHs in: a) Danube River sediments - part 1, b) Danube River sediments - part 2, c) Sava River sediments, and d) Sava River sediments downstream of Šabac. 
Table 6. TOC levels $\left(\mathrm{mg} \mathrm{g}^{-1}\right)$ in sediments from of the Danube River and its tributaries.

\begin{tabular}{|c|c|c|c|}
\hline $\begin{array}{c}\text { Sampling locations } \\
\text { along the Danube }\end{array}$ & TOC $^{1}$ & $\begin{array}{c}\text { Sampling locations } \\
\text { (tributaries } \\
\text { of the Danube) }\end{array}$ & TOC \\
\hline Tekija & 25.7 & Begej-Srpski Itebej & 43.8 \\
\hline Donji Milanovac & 10.0 & Begej-confluence of Tisa & 26.8 \\
\hline Ram & 12.5 & Tisa-Martonoš & 10.8 \\
\hline Novi Sad & 24.0 & Tisa-Novi Bečej & 14.3 \\
\hline Mihajlovac & 25.9 & Tisa-Titel & 24.5 \\
\hline
\end{tabular}

${ }^{1} \mathrm{TOC}=$ total organic carbon

measured in the Danube sediments and ranged from 265.1 to $11272 \mu \mathrm{g} \mathrm{kg}^{-1}$.

The PAH concentrations ranged from 10 to $4140 \mu \mathrm{g} \mathrm{kg}^{-1}$ in tributaries of the Danube. Furthermore, PAHs in sediments from the Sava were higher than those determined for the Danube and ranged from 265.1 to $11272 \mu \mathrm{g} \mathrm{kg}^{-1}$.

Graphic representations of the concentrations of PAHs in Danube and Sava sediments are given in Fig. 2.

PAHs in the river sediments were under the limits allowed by Dutch legislation (target and MAC values; Table 2), excluding the Sava River sediment taken downstream of Šabac.

The TOC in sediments from the Danube and its tributaries ranged from $10.0 \mathrm{mg} \mathrm{g}^{-1}$ to $43.8 \mathrm{mg} \mathrm{g}^{-1}$ (Table 6). The $\mathrm{pH}$ of sediments from the Danube and its tributaries ranged from 7.63 to 8.15 .

TOC levels in Sava sediments ranged from $11.1 \mathrm{mg} \mathrm{g}^{-1}$ to $22.7 \mathrm{mg} \mathrm{g}^{-1}$ (Table 7), while $\mathrm{pH}$ ranged from 7.76 to 8.10 .

To estimate the vulnerability of PAHs to abiotic and biotic degradation, and their toxicity and effect on humans, evaluation of sediment's physicochemical characteristics is very useful [42]. TOC is often positively correlated with organic contamination, while biochemical degradation of PAHs depends on the $\mathrm{pH}$ of the environment. Therefore, determining a sediment's

Table 7. TOC levels $\left(\mathrm{mg} \mathrm{g}^{-1}\right)$ in Sava River sediments.

\begin{tabular}{|c|c|c|c|}
\hline Sampling location & TOC $^{1}$ & $\begin{array}{c}\text { Sampling } \\
\text { location }\end{array}$ & TOC \\
\hline Jamena & 11.4 & Sava Skela & 21.6 \\
\hline $\begin{array}{c}\text { Downstream } \\
\text { of Sremska Mitrovica }\end{array}$ & 21.8 & Sava Zabran & 20.7 \\
\hline $\begin{array}{c}\text { Upstream of Sremska } \\
\text { Mitrovica }\end{array}$ & 20.1 & Sava Duboko & 12.4 \\
\hline $\begin{array}{c}\text { Sava downstream } \\
\text { of Šabac }\end{array}$ & 22.7 & Sava Makiš & 12.5 \\
\hline Sava Kapetanija & 15.4 & Sava Ostružnica & 11.1 \\
\hline
\end{tabular}

${ }^{1} \mathrm{TOC}=$ total organic carbon

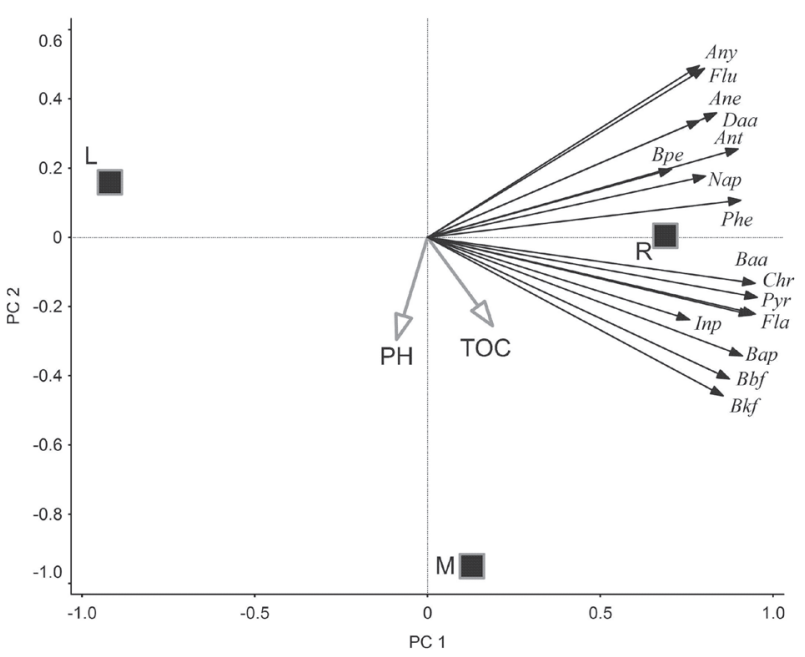

Fig. 3. Principal component analysis showing the relationship between PAHs, side of the river (squares: R-right, L-left, $\mathrm{M}$-middle), TOC and $\mathrm{pH}$ (PC1).

physicochemical characteristics and the consequent possibility of PAH degradation is an important indicator for judging the effectiveness of any bioremediation process. The evaluation of PAH behaviour and the sediment physicochemical characteristics ( $\mathrm{pH}$ and TOC) are relevant to bioavailability, environmental protection, multi-media partitioning behaviour and resistance to biotic and abiotic degradation [43, 44]. PCA was used to study the relationship between PAHs, side of the river, TOC and $\mathrm{pH}$, and is presented in Fig. 3. A higher concentration of the PAHs was found on the right side of the rivers compared to the left. Sediments from the middle of the river $(\mathrm{M})$ were more correlated to benzo $[a]$ anthracene, chrysene, pyrene, fluoranthene, indeno $[1,2,3-c d]$ pyrene, benzo $[a]$ pyrene, benzo $[b]$ fluoranthene and benzo[k]fluoranthene, as well as TOC. However, $\mathrm{pH}$ showed positive correlation only with benzo $[a]$ pyrene, benzo[b]fluoranthene and benzo $[k]$ fluoranthene and TOC.

The content of organic carbon in sediment has an important role in the retention of PAHs in soil and sediments [45-48]. A higher TOC means a higher amount of PAH can be absorbed [49].

\section{Identifying PAH Sources}

Two ratios of specific PAHs, Ant/(Ant+Phe) and Fla/ (Fla+Pyr), were considered as suitable to indicate the origins of the PAHs in river sediments [50, 51].

PAH isomer ratios, Ant/(Ant+Phe) and Fla/(Fla+Pyr), were used to confirm PAH sources at the 31 sampling locations (Fig. 4.). The Fla/(Fla+Pyr) ratio of 0.5 can be used to differentiate between pyrolytic and petrogenic origins. A Fla/(Fla $+\mathrm{Pyr})$ ratio of under 0.4 indicates petroleum products, 0.4 to 0.5 indicates liquid fossil fuel combustion, and above 0.5 indicates grass, wood or coal combustion [52].

All the sediments had high concentrations of HMW 


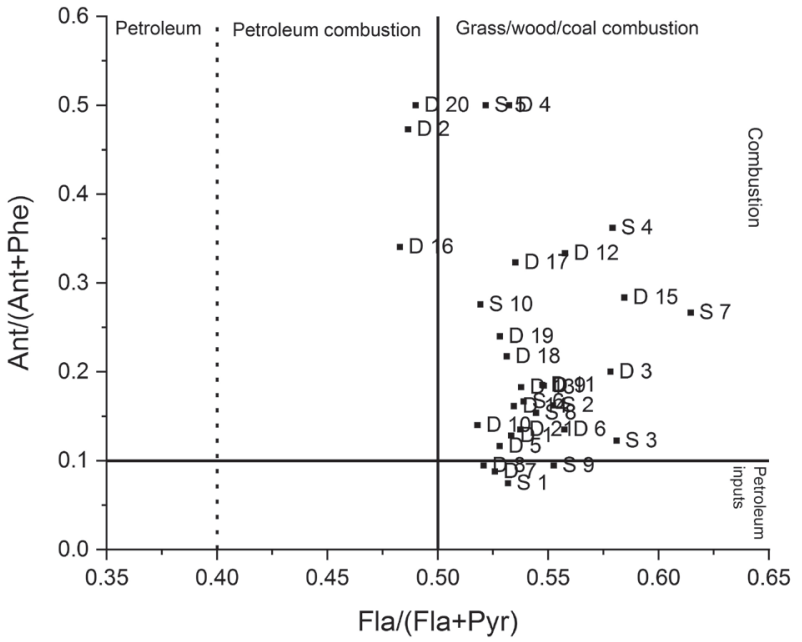

Fig. 4. Diagnostic ratio plots of Fla/(Fla+Pyr) vs. Ant/(Ant+Phe) in Danube and Sava river sediments.

PAH (4-6 rings), with Fla being the predominant compound in most locations. Ratioplots of Ant/ (Ant+Phe) versus Fla/(Fla+Pyr) showed that the PAHs were mainly derived from pyrogenic combustion, such as grass, wood and coal combustion [53].

From Fig. 4., the Fla/(Fla+Pyr) ratio varied from 0.46 to 0.63 , with average values of 0.53 and 0.55 for Fla and Fla+Pyr, respectively, for the Danube and Sava rivers. Since these values were above 0.5 in all sediments, this suggested that these PAHs were predominantly of pyrogenic origin. The ratios $\Sigma \mathrm{LMW} / \Sigma \mathrm{HMW}$ were $<1$ (0.340), for all the sampling locations, supporting the fact that the source of these PAHs was more likely to be the result of biomass or coal combustion.

Fla is less thermodynamically stable than Pyr and a predominance of the first compound over the second one is characteristic of pyrolytic sources. In the sediments, Fla (a 4-ring PAH) proved to be the most significant pollutant. Generally, greater concentrations of HMW PAHs than LMW PAHs were found in all sampling locations. Based on the studied source definition criteria, the PAH contaminants in the river sediments were mainly of pyrogenic origin. The PAHs from petrogenic input are usually characterised by high phenanthrene levels. As shown in Fig. 4, an Ant/(Ant+Phe) ratio above 0.1 indicated combustion processes, whereas a ratio below 0.1 corresponded to petroleum contamination. The contribution of petrogenic sources to the PAHs in the river sediments was also evident at some sampling locations (D2, D16 and D20).

\section{Conclusions}

PAHs in Danube River sediments in 2016 ranged from 278.0 to $1675 \mu \mathrm{g} \mathrm{kg}^{-1}$. In Sava River sediments PAHs were found to be higher than those measured in the Danube, ranging from 265.1 to $11272 \mu \mathrm{g} \mathrm{kg}^{-1}$. Also,
PAHs in sediments from other Danube tributaries ranged from $10 \mu \mathrm{g} \mathrm{kg}^{-1}$ to $4140 \mu \mathrm{g} \mathrm{kg}^{-1}$. These results show that the Danube River sediments sampled are mostly not seriously polluted, according to both the Serbian and Dutch regulatory systems. However, the Sava River sediment at location S4, downstream from Šabac, is more polluted with PAHs. At this location, PAHs in the sediment are higher than the targeted and MAC values, but still lower than the level indicating that remediation is necessary, so the sediment at this location is class 3 . The PAHs in sediments from the Sava and Danube in 2016 are similar to the values published in 2008 and 2013 [36, 54].

The sediment organic carbon content plays an important role in controlling PAH concentrations in the sediments. According to the PCA performed, TOC is positively correlated with benzo $[a]$ anthracene, chrysene, pyrene, fluoranthene, indeno[1,2,3-cd]pyrene, benzo[a] pyrene, benzo $[b]$ fluoranthene and benzo $[k]$ fluoranthene.

According to the ratios of anthracene/ (anthracene+phenanthrene) and fluoranthene/ (fluoranthene+pyrene), the PAHs in most of these river sediments originate from pyrogenic sources.

In conclusion, the river sediments from the Danube and Sava rivers and their tributaries are mostly not seriously polluted with PAHs according to Serbian regulation and the Dutch national evaluation scheme. Information on levels of PAHs in ecosystems in and around the Danube and Sava rivers in Serbia, such as that provided in the current study, is required as a basis for implementing a permanent systematic approach in this region to protect and improve river sediment quality.

\section{Acknowledgements}

The authors acknowledge the financial support of the Ministry of Education, Science and Technological Development of the Republic of Serbia (project No. 172013).

\section{Conflict of Interest}

The authors declare no conflict of interest.

\section{References}

1. MASIH A., LAL J.K. Concentrations and carcinogenic profiles of polycyclic aromatic hydrocarbons (PAHs) in groundwater of an urban site at a terai belt of North India. Int. J. of Appl. Eng. Res. 9 (1), 1, 2014.

2. EHRENHAUSER F.S., PAH and IUPAC Nomenclature. Polycyclic Aromatic Compounds. 3, 161, 2015.

3. KUPPUSAMY S., THAVAMANI P., MEGHARAJ M., NAIDU R. Biodegradation of polycyclic aromatic hydrocarbons (PAHs) by novel bacterial consortia tolerant to diverse physical settings - Assessments in liquid- and 
slurry-phase systems. Int. Biodeterior. and Biodegradation. 108, 149, 2016.

4. LI T., WANG Y., GUO S., LI X., XU Y., WANG Y., LI X. Effect of polarity-reversal on electrokinetic enhanced bioremediation of Pyrene contaminated soil. Electrochimica Acta. 187, 567, 2016.

5. ABDEL-SHAFY H.A., MANSOUR M.S.M. A review on polycyclic aromatic hydrocarbons: Source, environmental impact, effect on human health and remediation. Egypt. J. Pet. 25 (1), 107, 2016.

6. BAEK S.O., FIELD R.A., GOLDSTONE M.E., KIRK P.W., LESTER J.N., PERRY R.A. Review of atmospheric polycyclic aromatic hydrocarbons: sources, fate and behaviour. Water, Air and Soil Pollution. 60, 279, 1991.

7. MANOLI E., SAMARA C., KONSTANTINOU I., ALBANIS T. Polycyclic aromatic hydrocarbons in the bulk precipitation and surface waters of Northern Greece. Chemosphere. 41, 1845, 2000.

8. HSU W.T., LIU M.C., HUNG P.C., CHANG S.H., CHANG M.B. PAH emissions from coal combustion and waste incineration. J. Hazard. Mater. 318, 32, 2016.

9. RIBEIRO J., SILVA T., MENDONICA FILHO J.G., FLORES D. Polycyclic aromatic hydrocarbons (PAHs) in burning and non-burning coal waste piles. J. Hazard. Mater. 199, 105, 2012.

10. CHEN H.Y., TENG Y.G., WANG J.S., SONG L.T, ZUO R. Source apportionment of sediment PAHs in the Pearl River Delta region (China) using nonnegative matrix factorization analysis with effective weighted variance solution. Sci. Total Environ. 444, 401, 2013.

11. LIU Y., BECKINGHAM B., RUEGNER H., LI Z., MA L., SCHWIENTEK M., XIE H., ZHAO J., GRATHWOHL P. Comparison of sedimentary PAHs in the rivers of Ammer (Germany) and Liangtan (China): differences between early- and newly-industrialized country. Environ. Sci. Technol. 47 (2), 701, 2013.

12. WANG X.T., MIAO Y., ZHANG Y., LI Y.C., WU M.H., YU G. Polycyclic aromatic hydrocarbons (PAHs) in urban soils of the megacity Shanghai: Occurrence, source apportionment and potential human health risk. Sci. of The Total Environ. 447, 80, 2013.

13. BARRECA S., BASTONE S., CAPONETTI E., MARTINO D.F.C., ORECCHIO S. Determination of selected polyaromatic hydrocarbons by gas chromatography-mass spectrometry for the analysis of wood to establish the cause of sinking of an old vessel (Scauri wreck) by fire. Microchemical Journal. 117, 116, 2014.

14. ERRIKSON A.C., NORDIN E.Z., NYSTRÖM R., PETTERSSON E., SWIETLICKI E., BERGVALL C., PAGELS J.H. Particulate PAH emissions from residential biomass combustion: Time-resolved analysis with aerosol mass spectrometry. Environ. Sci. Technol. 48, 7143, 2014.

15. REN C., WU Y., ZHANG S., WU L.L., LIANG X.G., CHEN T.H., ZHU Z.C., SOJINU S.O., WANG J.Z. PAHs in sediment cores at main river estuaries of Chaohu Lake: implication for the change of local anthropogenic activities. Environ Sci. Pollut. Res. Inter. 22 (3), 1687, 2015.

16. SUN C., ZHANG J., MA Q., CHEN Y., JU H. Polycyclic aromatic hydrocarbons (PAHs) in water and sediment from a river basin: sediment-water partitioning, source identification and environmental health risk assessment. Environ. Geochem. Health. 39, 1, 2016.

17. FERNANDO S., SHAW L., SHAW D., GALLEA M., VANDENDEN L., HOUSE R., VERMA D.K., BRITZ Mc KIBBIN P., MC CARRY B. E. Evaluation of Firefighter
Exposure to Wood Smoke during Training Exercises at Burn Houses. Environ. Sci. Tech. 50 (3), 1536, 2016.

18. YUNKER M.B., MACDONALD R.W., VINGARZAN R., MITCHELL R.H., GOYETTE D., SYLVESTRE S. PAH in the Fraser River basin: a critical appraisal of PAH ratios as indicators of PAH source and composition. Organic Geochemistry. 33, 489, 2002.

19. LIU M., FENG. J., HU P., TAN L., ZHANG X., SUN J. Spatial-temporal distributions, sources of polycyclic aromatic hydrocarbons (PAHs) in surface water and suspended particular matter from the upper reach of Huaihe River. Ecol. Eng. 95, 143, 2016.

20. ZHOU J.L., MASKAOUI K. Distribution of polycyclic aromatic hydrocarbons in water and surface sediments from Daya Bay, China. Environ. Pollut. 121, 269, 2003.

21. GURNELL A., LEE M., SOUCH C. Urban rivers: hydrology, geomorphology, ecology and opportunities for change. Geography Compass. 1 (5), 1118, 2007.

22. FRANZ C., MAKESCHIN, F., WEIß H., LORZ C. Sediments in urban river basins: Identification of sediment sources within the Lago Paranoá catchment, Brasilia DF, Brazil - using the fingerprint approach. Sci. Total Environ. 466, 513, 2014.

23. WEN Y., SCHOUPS G., VAN DE GIESEN N. Organic pollution of rivers: Combined threats of urbanization, livestock farming and global climate change. Scientific Reports. 7 (1), $43289,2017$.

24. LI H., RAN Y. Distribution and Bioconcentration of Polycyclic Aromatic Hydrocarbons in Surface Water and Fishes. The Scientific World Journal. 2012, 1, 2012.

25. SHAHPOURY P., HAGEMAN K.J., MATTHAEI C.D., ALUMBAUGH R.E., COOK M.E. Increased concentrations of polycyclic aromatic hydrocarbons in Alpine streams during annual snowmelt: investigating effects of sampling method, site characteristics, and meteorology. Environ. Sci. Technol. 48 (19), 11294, 2014.

26. PEVERLY A.A., O'SULIVAN C., LIU L.Y., VENIER M., MARTINEZ A., HORNBUCKLE K.C., HITES R.A. Chicago's sanitary and ship canal sediment: Polycyclic aromatic hydrocarbons, polychlorinated biphenyls, brominated flame retardants, and organophosphate ester. Chemosphere. 134, 380, 2015.

27. LI Y., DUAN X. Polycyclic aromatic hydrocarbons in sediments of China Sea. Environ. Sci. Pollut. Res. 22 (20), 15432, 2015.

28. RABODONIRINA S., NET S., OUDDANE B., MERHABY D., DUMOULIN D., POPESCU T., RAVELONANDRO P. Distribution of persistent organic pollutants (PAHs, Me-PAHs, PCBs) in dissolved, particulate and sedimentary phases in freshwater systems. Environ. Pollut. 206, 38, 2015.

29. KANNAN K., JOHNSON-RESTREPO B., YOHN S.S., GIESY J.P., LONG D.T. Spatial and temporal distribution of polycyclic Level and Spatial Distribution f Polycyclic Aromatic Hydrocarbons (PAHS) in sediments from Michigan inland lakes. Environ. Sci. Technol. 39 (13), 4700, 2005.

30. YAN W., CHI J., WANG Z., HUANG W., ZHANG G. Spatial and temporal distribution of polycyclic aromatic hydrocarbons (PAHs) in sediments from Daya Bay, South China. Environ. Pollut. 157 (6), 1823, 2009.

31. CHAWDA S., TARAFDAR A., SINHA A., MISHRA B.K. Profiling and Health Risk Assessment of PAHs Content in Tandoori and Tawa Bread from India. Polycyclic Aromatic Compounds. 1, 2017. 
32. RENGARAJAN T., RAJENDRAN P., NANDAKUMAR N., LOKESHKUMAR B., RAJENDRAN P. NISHIGAKI I. Exposure to polycyclic aromatic hydrocarbons with special focus on cancer. Asian Pac. J. Trop. Biomed. 5 (3), 182, 2015.

33. XIA G.S., BALL W.P. Adsorption-partitioning uptake of nine low-polarity organic chemicals on a natural sorbent. Environ. Sci. Technol. 33 (2), 262, 1999.

34. SAZAKLI E., SIAVALAS G., FIDAKI A., CHRISTANIS K., KARAPANAGIOTI K.H., LEOTSINIDIS M. Concentrations of persistent organic pollutants and organic matter characteristics as river sediment quality indices. Toxicol. Environ. Chem. 98, 787, 2015.

35. WU F., XU L, SUN Y, LIAO H., ZHAO X., GUO J. Exploring the relationship between polycyclic aromatic hydrocarbons and sedimentary organic carbon in three Chinese lakes. J. Soil. Sediment. 12 (5), 774, 2012.

36. CRNKOVIĆ D.M., CRNKOVIĆ N.S., FILIPOVIĆ A.J., RAJAKOVIĆ LJ.V., PERIC-GRUJIĆ A. Danube and Sava river sediment monitoring in Belgrade and its surroundings. J. Environ. Sci. Health, part A. 43 (12), 1353, 2008.

37. SAKAN S., OSTOJIĆ B., ĐORĐEVIĆ D. Persistent organic pollutants (POPs) in sediments from river and artificial lakes in Serbia. J. Geochem. Explor. 180, 91, 2017.

38. ANTONIJEVIĆ M.D., ARSOVIĆ M., ČÁSLAVSKÝ J., CVETKOVIĆ V., DABIĆ P., FRANKO M., ILIĆ G., IVANOVIĆ M., IVANOVIĆ N., KOSOVAC M., MEDIĆ D., NAJDANOVIĆ S., NIKOLIĆ M., NOVAKOVIĆ J., RADOVANOVIĆ T., RANIĆ Đ., ŠAJATOVIC B., ŠPIJUNOVIĆ G., STANKOV I., TOŠOVIĆ J., TREBŠE P., VASILJEVIĆ O., SCHWARZBAUER J. Actual contamination of the Danube and Sava rivers at Belgrade (2013). J. Serbian Chem. Soc. 79 (9), 1169, 2014.

39. INSTITUTE FOR STANDARDIZATION OF SERBIA, WATER QUALITY - SAMPLING - PART 12: Guidance on sampling of bottom sediments. SRPS ISO 566712:2005. Belgrade. 1, 2005.

40. LERDA D. Polycyclic aromatic hydrocarbons (PAHs) Factsheet. Joint Research Centre, Technical notes, $4^{\text {th }}$ edition. 27, 2011.

41. KIELBASA A., BUSZEWSKI B. PAH analytics in New Polish Reference Material. Pol. J. Environ. Stud. 24 (5), 2021, 2015.

42. JOHNSEN A.R., WICK L.Y., HARMS H. Principles of microbial PAH degradation in soil. Environ. Pollut. 133, (1), 71, 2005.

43. EMOYAN O.O., AKPORIDO S.O., AGBAIRE P.O. Seasonal Concentration Variation of Polycyclic Aromatic
Hydrocarbons (PAHs) of Soils at Sapele Municipality, Nigeria. Amer. J. Environ. Eng. and Sci. 2 (2), 9, 2015.

44. JANCEWICZ A., DMITRUK U., TOMCZUK U. Spatial distribution and potential toxicity assessment of selected PAHs in bottom sediments of polish reservoir. Carpath. J. Earth Environ. Sci. 10 (2), 107, 2015.

45. YANG Y., ZHANG N., XUE M., TAO S. Impact of soil organic matter on the distribution of polycyclic aromatic hydrocarbons (PAHs) in soils. Environ. Pollut. 158 (6), 2170, 2010.

46. AVRAMIDIS P., NIKOLAU K., BEKIARI V. Total Organic Carbon and Total Nitrogen in Sediments and Soils: A Comparison of the Wet Oxidation - Titration Method with the Combustion-infrared Method. Agriculture and Agricultural Science Procedia. 4, 425, 2015.

47. UKALSKA-JARUGA A., SMRECZAK B., KLIMKOWICZ-PAWLAS A. Soil organic matter composition as a factor affecting the accumulation of polycyclic aromatic hydrocarbons, J. Soils Sediments. 19 (4), 1890, 2018.

48. LIU Y.P., WANG Y.H., YE C., XIE B., YANG H. Sedimentary Record of Polycyclic Aromatic Hydrocarbons from the Shuanglong Catchment, Southwest China. J. Chem. 2017, 1, 2017.

49. WILCKE W. Synopsis polycyclic aromatic hydrocarbons (PAHs) in soil - a review. J. Plant. Nutr. Soil Sci. 163, 229, 2000.

50. TOBIESZEWSKI M., NAMIEŚNIK J. PAH diagnostic ratios for the identification of pollution emission sources. Environ. Pollut. 162, 110, 2012.

51. CHEN Y., SUN C., ZHANG. J, ZHANG F. Assessing 16 Polycyclic Aromatic Hydrocarbons (PAHs) in River Basin Water and Sediment Regarding Spatial-Temporal Distribution Partitioning, and Ecological Risks. Pol. J. Environ. Stud. 27 (5), 579, 2018.

52. KANZARI F., SYAKTI A.D., ASIA L., MALLERET L., PIRAM A., MILLE G., DOUMENQ P. Distributions and sources of persistent organic pollutants (aliphatic hydrocarbons, PAHs, PCBs and pesticides) in surface sediments of an industrialized urban river (Huveaune), France. Sci. Total Environ. 478, 141, 2014.

53. RASIQ K.T., EL-MARADNY A., EL AMIN-BASHIR M., ORIFF M., Polycyclic Aromatic Hydrocarbons (PAHs) in Surface Sediments of Two Polluted Lagoons in Saudi Arabia. Pol. J. Environ. Stud. 27 (1), 275, 2018.

54. BABIĆ MLADENOVIĆ M., KOLAROV V., DAMJANOVIĆ V. Sediment regime of the Danube River in Serbia. Int. J. Sediment Res. 28 (4), 470, 2013. 